\title{
Key directions of breeding and seed production of alfalfa in European Russia
}

\author{
V.I. Cherniavskih*, E.V. Dumacheva ${ }^{1}$, Z.A. Borodaeva ${ }^{1}$, D.V. Dumachev $^{2}$ \\ 1 Belgorod State Research University, Belgorod, Russia \\ ${ }^{2}$ Belgorod Oncology Dispensary, Belgorod, Russia
}

DOI 10.18699/ICG-PlantGen2019-73

Abstract: The aim of the work is to study the varieties and breeding samples of alfalfa in various ecotopes. Analysis of variance of the two-factor experiment showed that the resultative property 'productivity' primarily depends on the factor "ecotope" (68.7\%), while the factor "grade" determines it slightly (4.7\%). Their interaction does not have a strong impact (10.9\%). The share of the year conditions influence averaged $0.48 \%$. Analysis of variance of the two-factor experiment showed that the resultative property "seed yield" primarily depends on the factor "ecotope" (63.58\%), while the contribution of the factor "grade" is $5.45 \%$; the interaction of these factors has a significant impact (25.5\%). The share of the year conditions influence averaged $1.01 \%$.

Key words: alfalfa; various ecotope; mf-mutation; breeding; seed production.

\section{Introduction}

Alfalfa is one of the most important widespread ancient world cultures, which is a companion of intensive commercial livestock and livestock production, requiring for its development a solid, stable and high-quality forage base. Alfalfa is a culture of multidisciplinary use. It is demanded both in agricultural production and in medicine and pharmacology. At the present stage, the most intensive breeding work is being carried out with several species of the genus Medicago: M. sativa L. and M. varia Mart. (Lamb et al., 2007; Kurkina et al., 2017).

An important direction in the global breeding of alfalfa is the study of forms carrying a recessive genetic mutation of multiflora (mf-mutation). This mutation is controlled by a recessive gene $(m j)$ and two genes that affect its expression (Bingham, Murphy, 1965; Petkova, 2010; Popescu et al., 2016). The mutation manifests most clearly in difficult environmental conditions and such forms show indicators of high quality (Dumacheva et al., 2018).

Successful breeding work requires the creation of a system of sustainable seed production as an economic basis for the effective implementation of scientific achievements. The close cooperation of scientists of the Belgorod State University with one of the largest enterprises of the region, ZAO "Prioskolye", enabled the creation of a system for primary and elite alfalfa seed production based on the author varieties. The area of alfalfa tested in some years has reached 1.5 thousand hectares and the production of seeds with high reproduction rate, 300 tons/year. The investment from the use and sale of seeds makes it possible to finance breeding programs that use the method of recurrent selection, the method of polycross, the method of hybridization using mf-mutations, microclonal reproduction.

The aim of the work is to study the varieties and breeding samples of alfalfa in various ecotopes; to elect source material for the selection of specialized varieties for special conditions of cultivation.

\section{Materials and methods}

The research was carried out in 2016-2018 in the Chernyansky branch of the experimental plots of ZAO "Krasnoyaruzh- skaya zernovaya kompaniya", Belgorod region, Chernyansky district.

The plants were sown in the standard trial design. The plot area was $2 \mathrm{~m}^{2}$. The repetition was fourfold. The plots were double-row. The row spacing in the plot was $25 \mathrm{~cm}, 45 \mathrm{~cm}$ between the plots. Control varieties were placed through 4 plots. As the standard, the variety Krasnoyaruzhskaya 1 was chosen, which was adopted as a regional standard during the State variety testing in 5 regions.

Trial variations:

A-factor (variety population):

A1: a zoned variety of $M$. varia Krasnoyaruzhskaya 1;

A2: a zoned variety of $M$. varia Krasnoyaruzhskaya 2;

A3: Vega 87;

A4: the breeding varieties of $M$. varia PPL 6/8;

A5: the variety population NZK $40 \mathrm{mf}$, which was obtained as a result of sampling from the local populations of $M$. varia growing in the floodplains of the Belgorod region on the basis of the presence of the mf-mutation. The selection condition was the expression of the mf-mutation above ' 3 ' and a high degree of wax on the leaves.

B: factor (ecotope, soil difference):

B1: soil: chernozem typical, heavy-loamy, which was in a field crop rotation. The humus content was $5.1 \%$, the content of easily hydrolyzed nitrogen was $182 \mathrm{mg} / \mathrm{kg}, \mathrm{P}_{2} \mathrm{O}_{5}$ concentration was $235 \mathrm{mg} / \mathrm{kg}, \mathrm{K}_{2} \mathrm{O}$ concentration was $292 \mathrm{mg} / \mathrm{kg}$, $\mathrm{pH}_{\mathrm{KCl}}$ was 6.5;

B2: meadow-gley, light-loamy soil, on the plowed meadow in the floodplain of the Oskol river;

B3: chernozem leached, sandy-loam, which was in the byfarm crop rotation. The humus content was $1.9 \%$, the content of easily hydrolyzed nitrogen was $1-84 \mathrm{mg} / \mathrm{kg}, \mathrm{P}_{2} \mathrm{O}_{5}$ concentration was $159 \mathrm{mg} / \mathrm{kg}, \mathrm{K}_{2} \mathrm{O}$ concentration was $140 \mathrm{mg} / \mathrm{kg}$, $\mathrm{pH}_{\mathrm{KCl}}$ was 6.3.

Agrochemical studies of experimental plots were performed according to standard methods adopted in agrochemistry: humus was analyzed by the Tyurin method; easily hydrolyzed nitrogen, by the Kornfield method; mobile phosphorus and potassium compounds, by the Chirikov method. For equalizing planting the white mustard culture was used. Sowing 
was carried out using a "Klen 5.4" electronic drill. Seeds were sown at a rate of 100 pieces per running meter.

The expression index was calculated as the sum of multiplication of number of plants (tillers) in each mf category on total number of plants (tillers) in population. Categories of mf: 0, lack of mutation; 1, 1 mf-leaf on one stalk; 2, 2-3 mf-leaves on one stalk; 3, 4-5 mf-leaves on one stalk; 4, 6-7 mf-leaves on one stalk; 5 , more than $8 \mathrm{mf}$-leaves on one stalk (Sheaffer et al., 1995). Statistical data processing was carried out with the use of the common software Microsoft Excel (2010).

\section{Results and discussion}

Selection work with alfalfa as a fodder crop is mainly aimed at achieving several main objectives: increasing the productivity of the forage mass in specific soil and climatic conditions, increasing the collection of protein per unit area and increasing the digestibility of the forage mass. In parallel, the work for increasing seed productivity as the basis for effective seed production is underway. The collection of dry matter obtained during the growing season of all variety samples in all studied ecotopes was calculated as an average for three years of research, which contributed to a full understanding of the processes of biomass formation during the growing season of alfalfa.

The first group included the variety samples both with a high rate of mf mutation (NZK $40 \mathrm{mf}, \mathrm{A} 5$ ) and a low gene expression ('Krasnoyaruzhskaya 2', A2), which have shown productivity at the standard level on average during the years of research. At the same time, on the chernozem soils, the variety Krasnoyaruzhskaya 2 (A2) had significantly exceeded the standard, by $24.7 \%(\mathrm{Cv}=0.1 \%)$, and NZK $40 \mathrm{mf}(\mathrm{A} 5)$ showed productivity at the standard level $(\mathrm{Cv}=3.5 \%)$.

The yield of dry phytomass from alfalfa of the NZK 40 mf variety sample (A5) on the meadow soil (an average over 3 years of research) was higher than the standard by $87.5 \%$ $(\mathrm{CV}=5.9 \%)$. In individuals of 'Krasnoyaruzhskaya 2' (A2), on a meadow soil, productivity remained at the level of the standard (the variety Krasnoyaruzhskaya 1). On the sandy soils, the individuals of the variety populations of this group were close to the standard in phytomass productivity and did not exceed it by more than 4.9-5.6 \% $(\mathrm{Cv}=16.7-17.9 \%)$.

The second group was formed by the variety Vega 87 (A3) and PPL 6/8 (A4) populations. On average, over the years of research in all ecotopes, they showed higher productivity than the standard. The variety Vega 87 (A3) population had shown productivity at the standard level only on the chernozem soils, and exceeded it by 22.3 and $10.2 \%$ on the meadow and sandy soils, respectively. Individuals of the PPL 6/8 variety population (A4) showed above-ground productivity above the standard by $41.4 ; 28.6$ and $10.5 \%$ in all ecotopes, respectively $(\mathrm{Cv}=2.2-14.2 \%)$.

One of the important directions of research was assessing the tolerance of varieties and variety populations in the same ecotope conditions based on the degree of yield reduction. The alfalfa variety populations studied in the experiment were divided into several groups according to seed yield under different ecotopes. The research results showed that such variety populations as Vega 87 (A3) and NZK $40 \mathrm{mf}$ (A5) had shown a good ecological suitability for meadow soils. Their average yield was $32.83 \mathrm{~g} / \mathrm{m}^{2}$ on the chernozem soils; on the sandy soils their productivity decreased by 50.2 and $70.3 \%$. On the meadow soils, the individuals had reduced their yield only by $13.97 \%$, and in the variety A5 yield it remained at the standard level $(\mathrm{Cv}=4.3 \%)$. These forms had a general morphological difference from other forms, a pronounced waxy coating on the leaves. In the areas with chernozem soil, a new promising variety sample, PPL 6/8 (A4), had shown its yield at the level of the varieties in the first group at $\mathrm{CV}=11.5 \%$. On sandy soil, the yield decreased by $36.56 \%(\mathrm{Cv}=6.1 \%)$; on meadow, by $72.4 \%(\mathrm{Cv}=33.1 \%)$.

\section{Conclusions}

The zoned varieties Krasnoyaruzhskaya 1 and Krasnoyaruzhskaya 2 are differentially recommended for cultivation in the conditions of intensive crop rotation and low-productivity soils.

Analysis of variance of the two-factor experiment showed that the resultative property "productivity" primarily depends on the factor "ecotope" $(68.7 \%)$, the factor "Grade" determines it slightly $(4.7 \%)$. Their interaction does not have a strong impact $(10.9 \%)$. The share of the year conditions influence averaged $0.48 \%$.

Analysis of variance of the two-factor experiment showed that the resultative property "seed yield" primarily depends on the factor "ecotope" $(63.58 \%)$, while the contribution of the factor "grade" is $5.45 \%$; the interaction of these factors has a significant impact $(25.5 \%)$. The share of the year conditions influence averaged $1.01 \%$.

\section{References}

Bingham E.T., Murphy R.P. Breeding and morphological studies on Multifoliolate selections of alfalfa Medicago sativa L. Crop. Sci. 1965;5:233-235.

Dumacheva E.V., Cherniavskih V.I., Gorbacheva A.A., Vorobyova O.V., Borodaeva Z.A., E.N. Bespalova and Ermakova L.R. Biological resources of the Fabaceae family in the cretaceous south of Russia as a source of starting material for drought-resistance selection. International J. Green Pharmacy. 2018;12(2):354-358. DOI 10.22377/ijgp.v12i02.1785

Kurkina Y.N., Huong N.T.L., Lazarev A.V., Dumacheva E.V., Cherniavskich V.I. Features of morphology and biology of broad bean samples in the south of the central black earth region (Russia). International J. Green Pharmacy. 2017;11(3):494-497. DOI 10.22377/ ijgp.v11i03.1163

Lamb J.F.S., Jung H.-J.G., Sheaffer C.C., Samac D.A. Alfalfa leaf protein and stem cell wall polysaccharide yields under hay and biomass management systems. Crop Science Society of America. 2007;47:1407-1415.

Petkova D. Multifoliate Alfalfa line with 23-24 leaves on a leaf stalk. $J$. Crop Weed. 2010; 6(1):1-5.

Popescu S., Boldura O.-M., Ciulca S. Evaluation of the geneticvariability correlated with multileaflet trait in alfalfa. AgroLife Scientific Journal. 2016;5(2):125-130.

Sheaffer C.C., McCaslin M., Volenec J.J., Cherney J.H., Johnson K.D., Woodward W.T., Viands D.R. Multifoliolate Leaf Expression (Leaves With Greater Than 3 Leaflets. Leaf). 1995:2.

Acknowledgements. The study was supported by the grants: for the research and development on priority directions of development of agro industrial complex of the Belgorod region (Agreement No. 2 dated November 12, 2018); grant No. 6.4854.2017/BCh.

Conflict of interest. The authors declare no conflict of interest. 